\title{
Ensuring Economic Benefits of Mitigation Projects for Improving the Image of Construction Industry ${ }^{\dagger}$
}

\author{
Chang-Baek Son ${ }^{1)}$, Won-Sang Shin ${ }^{2)}$, and Dae Young $\mathrm{Kim}^{3)}$
}

\begin{abstract}
Over the last several decades, the United States has experienced a great number of natural disasters. To minimize the impact of the natural hazard events, the U.S. government spent a tremendous amount of money through federal assistant programs. To be eligible for the programs, a mitigation project must be cost effective (more benefits compared to project costs). However, the state and local communities suffering from the natural disasters generally have difficulty in collecting reliable evidence for their damages which can be converted later into benefits when a mitigation project is implemented. Therefore, this paper shows the process of conducting a benefit cost analysis with limited data. Besides, it also provides how to apply the limited data to the analysis through a case study. Consequently, this paper help state and local communities get funding from the federal government, which in turns will improve the image of construction industry by preventing people from natural disasters.
\end{abstract}

Key Words : natural hazards, disasters, flooding, mitigation capital improvement projects, benefit cost analysis (BCA), and improvement of construction image

\section{Introduction and Background}

Over the last several decades, the United States has experienced a great number of natural disasters. In particular, Hurricane Sandy, the deadliest and most destructive hurricane, in 2012, killed more than 100 people and inflicted over 75 billion dollars in damage [1]. According to a recent report by Federal

† This work was supported by Basic Science Research Program through the National Research Foundation of Korea (NRF) funded by the Ministry of Education (NRF-2013R1A1A2009500) and Dong-Eui University Grant (No. 2013AA119)

1) Professor, Dept. of Architectural Engineering, Semyung University, First Author.

2) $\mathrm{PhD}$ Candidate, Dept. of Construction Engineering, Semyung University.

3) Assistant Professor, Dept. of Architectural Engineering, Dong-Eui University, Corresponding Author.
Emergency Management Agency (FEMA), the State of Texas alone has experienced 83 federally-declared disasters over the past 50 years, resulting in hundreds of victims and billions of dollars in damages [1]. Compared to other states, Texas is more vulnerable to natural hazards because it is located at the intersection of multiple climate zones and lies along the Gulf Coast [2].

A natural hazard is a potential threat which has a negatively impact on people and the environment resulting from severe and extreme weather and climate events. These hazards typically include earthquake, avalanche, drought, heat wave, tornado, and cyclonic storms. Hazard mitigation is defined by the U.S. government accounting office (GAO) as "actions taken before or after a natural hazard event to reduce or eliminate the long-term risks to life 
Ensuring Economic Benefits of Mitigation Projects for Improving the Image of Construction Industry

and property from natural hazard [3]." In addition, FEMA described hazard mitigation planning as "the process the governments use to identify risks and vulnerabilities associated with natural hazards and to develop long-term strategies for protecting people and property in future hazard events [3, 4]." Based on those definitions, a hazard mitigation action is a conceptual idea about how to reduce the vulnerability of hazard events [5]. A mitigation capital project, however, is "a very specific set of activities that can be implemented and typically require a detailed scope of work, cost estimate, schedule, and may require preliminary engineering design, such as 'Increase the capacity of Ditch $A$ from 4,000 cubic feet per second of discharged water to 6,000 cubic feet per second of discharged water'with an appropriate preliminary design that shows how to achieve the increase in capacity [6]."

It is impossible to prevent a natural hazard event itself however, human efforts can reduce its impact on people and property by taking advanced actions that mitigate risks of natural disasters [7]. The United State spent a tremendous amount of money to protect or minimize the impacts of natural disasters. In October 2000, the Disaster Mitigation Act of 2000 (DMA 2000) was passed by the United States Congress to advocate the need for hazard mitigation planning. As a result, local communities can implement natural hazard mitigation capital projects supported by federal funding through several FEMA's hazard assistant programs. These grant programs include hazard mitigation grant program (HMGP), flood mitigation assistance (FMA), pre-disaster mitigation (PDM). Repetitive flood claims (RFC), and severe repetitive loss (SRL). Although the requirements of these programs are different each other, the common goal of these programs is to provide funds to state and local communities to reduce impact from future natural hazard events.

In current practice, different types of mitigation capital improvement projects are performed to protect or minimize the impact of future hazard events. These typically include acquisition, relocation, elevation, storm drainage system, structural flood control measure, retrofit, individual

$<$ Table 1> Characteristics of Various Mitigation Capital Improvement Projects

\begin{tabular}{|c|c|c|}
\hline Alternatives & $\begin{array}{l}\text { Hazard } \\
\text { Type } \\
\end{array}$ & Characteristics \\
\hline Acquisition & Flood & $\begin{array}{l}\text { - Permanently solve the } \\
\text { problem } \\
\text { - Are not subject to } \\
\text { maintenance budget } \\
\text { cuts } \\
\text { - Reduce flooding in } \\
\text { remaining } \\
\text { neighborhoods } \\
\text { - Can be quickly } \\
\text { - And are not affected } \\
\text { by increasing flood } \\
\text { heights due to } \\
\text { upstream development }\end{array}$ \\
\hline Relocation & Flood & $\begin{array}{l}\text { - May be moved to a } \\
\text { less hazardous } \\
\text { location }\end{array}$ \\
\hline Elevation & Flood & $\begin{array}{l}\text { - May be mechanically } \\
\text { lifted above the base } \\
\text { flood elevation }\end{array}$ \\
\hline $\begin{array}{l}\text { Storm } \\
\text { Drainage } \\
\text { Systems }\end{array}$ & Flood & $\begin{array}{l}\text { - Can involve installing, } \\
\text { re-routing, or } \\
\text { increasing the } \\
\text { capacity of a storm } \\
\text { drainage system }\end{array}$ \\
\hline $\begin{array}{l}\text { Structural } \\
\text { Flood } \\
\text { Control } \\
\text { Measures }\end{array}$ & Flood & $\begin{array}{l}\text { - May increase } \\
\text { drainage or absorption } \\
\text { capacities, } \\
\text { - Include levees, dams, } \\
\text { or floodwalls }\end{array}$ \\
\hline Retrofit & Hurricane & $\begin{array}{l}\text { - Harden structures or } \\
\text { utility systems to } \\
\text { withstand natural } \\
\text { events, } \\
\text { - Include adding } \\
\text { hurricane shutters to } \\
\text { windows, } \\
\text { - And replace window } \\
\text { glass with high-strength } \\
\text { lexan glass }\end{array}$ \\
\hline $\begin{array}{l}\text { Individual } \\
\text { Safe Room }\end{array}$ & Tornado & $\begin{array}{l}\text { - Reinforced room built } \\
\text { in a new or existing } \\
\text { structure }\end{array}$ \\
\hline $\begin{array}{l}\text { Community } \\
\text { Shelter }\end{array}$ & Tornado & $\begin{array}{l}\text { - Multi-use shelters } \\
\text { may be done }\end{array}$ \\
\hline
\end{tabular}


safe room, and community shelter. The types of the projects are designed for specific hazards including floods, hurricanes, and tornados. The general definitions of the projects are summarized below in Table $1[8,9]$.

\section{Research Needs and Motivations}

In the mitigation planning, project evaluation is a critical process for developing alternative projects and identifying the most effective mitigation project. Unlike other capital projects, mitigation projects inherently own greater risk and are uneasy to quantify their objectives. However, the current project decisions relying on simple scoring worksheets are insufficient in addressing multiple and competing objectives and inappropriate to assess project effectiveness. Further, the state and local communities currently face increasing demands for proactive mitigation planning that reflects selecting effective projects. With a lack of appropriate models, the state and local communities are not able to carry out better mitigation planning. Therefore, there is critical need to develop a systematic decision model for selecting the effective mitigation project.

In addition, most of the hazard assistant programs determine mitigation projects based on the benefit cost analysis (BCA). The BCA compares project costs and benefits over the life of the mitigation project. Based on the result of the analysis, mitigation projects that are expected to have greater benefits than costs may be selected for the funding programs. However, many people who suffered flood damage frequently complain difficulties in preparing and collecting data required for the BCA. Therefore, it is needed a more simplified but reliable method that can produce a benefit cost ratio (BCR) to help local communities and state government be eligible for the programs.

\section{Research Methodology}

The primary purpose of this paper is to provide an alternative method to conduct benefit cost analysis (BCA) with limited data in selecting natural hazard mitigation capital improvement projects. The $\mathrm{BCA}$ is a technique used to determine the relative project benefits compared to total project costs. Eventually, it determines whether to proceed with the planned project based on the benefit cost ratio (BCR). To conduct a benefit cost analysis, the following steps are needed:

1. Quantify project costs: costs are measured by the amount of money to implement the planned project including future maintenance costs. These costs can be estimated based on the scope of work, preliminary engineering and design.

2. Quantify project benefits: benefits are measured by avoided future damage that will result from the completion of the planned project.

3. Determine benefit cost ratio: the quantified project benefits and costs in previous steps are compared to produce the BCR. A planned project with the ratio of greater than 1 is typically considered to be cost effective project.

The basic steps for collecting benefits and costs data required are described below in Fig. 1. 
Ensuring Economic Benefits of Mitigation Projects for Improving the Image of Construction Industry

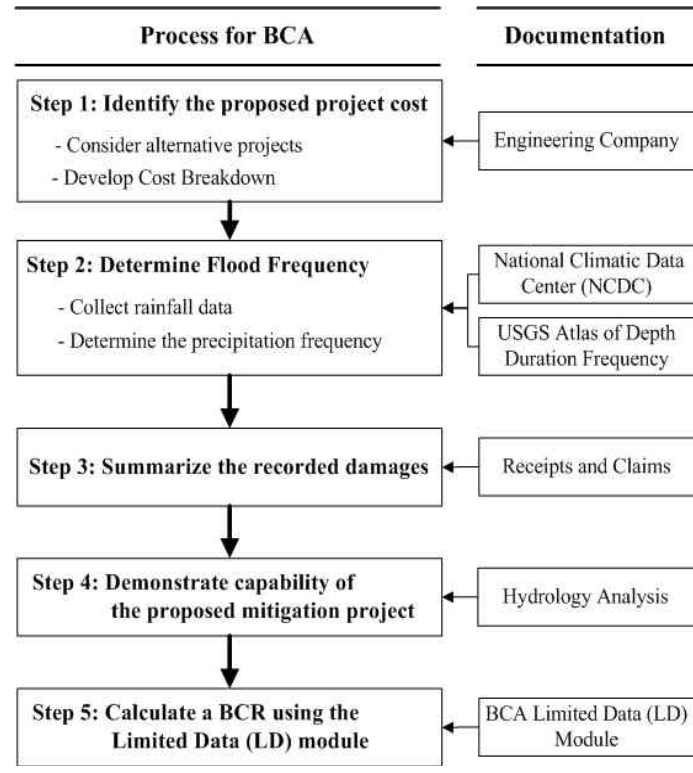

$<$ Fig. 1 $>$ Research Methodology

\section{A Case Study}

\subsection{Situation of the Case}

This case was a project finally approved in 2009 by the United States Hazard Mitigation Grant Program (HMGP). The detailed situation of the case is described below:

The two-culvert drainage system was installed in 1996 and was reportedly designed for a 25-year event. Two 96-inch reinforced concrete culverts allow water to flow through the dry creek bed. This creek is owned by private land owners in the headwater area. When large rains occur, the current two-culvert drainage system quickly becomes a dam because debris gets caught in the openings. This damming causes flooding of the residents' homes along the dry creek.

The two-culvert system and associated bridge begin to overtop at a less than 10-year event although the calculations indicate that the culverts can handle a 25-year event. The residents have experienced flooding several times since the current

culvert system was installed. The water level in the homes was one to two feet deep destroying floors, rugs, furniture, walls, and causing mold issues.

\subsection{Description of the Proposed Project}

The current drainage system consists of two 96-inch reinforced concrete culverts to allow water to flow in the creek. These two openings are frequently dammed up with debris and increase the peak discharge of the water, which causes the flooding and damage to the homes. The proposed alternative involves (1) removing two 96-inch diameter culverts, associated concrete wing walls, and concrete road structure; (2) excavating and cleaning the channel so that it is restored to its natural condition as much as possible, and (3) installation of a structure that permits vehicles to cross the channel. The detailed scope of the project includes below:

- Demolition of the existing two-culvert drainage system

- Dispose of exiting two-culvert structure

- Engineering layout for the work

- Two each reinforced concrete abutments and wing walls founded on drilled shafts

- TxDOT standard 40' pan girder concrete bridge, 30degree skew

-18" Concrete rail

- Reinforced concrete riprap slope protection

- Barricades and traffic control

- Channel cleaning from the dam to approximately 200 yards downstream of the bridge to restore the dry channel to its natural condition as much as possible

\subsection{The Cost Breakdown of the Project}

The cost breakdown of the proposed mitigation project is summarized in Table 2. 
$<$ Table 2> Cost Breakdown of the Project

\begin{tabular}{|c|c|c|c|c|}
\hline No & Description & Unit & Qty & $\begin{array}{c}\text { Total } \\
\text { Price }(\$)\end{array}$ \\
\hline 1 & Removal of old structure & EA & 1 & 50,000 \\
\hline 2 & 24" Drill shafts & $\mathrm{LF}$ & 180 & 54,000 \\
\hline 3 & $\begin{array}{l}\text { Reinforced concrete } \\
\text { abutment }\end{array}$ & $\mathrm{CY}$ & 202 & 28,280 \\
\hline 4 & $\begin{array}{l}\text { Reinforced concrete } \\
\text { bridge }\end{array}$ & $\mathrm{CY}$ & 565 & 67,800 \\
\hline 5 & $\begin{array}{l}\text { Reinforced concrete } \\
\text { bridge rail }\end{array}$ & $\mathrm{LF}$ & 120 & 37,200 \\
\hline 6 & $\begin{array}{l}5^{\prime} \text { Reinforced concrete } \\
\text { slope protection }\end{array}$ & CY & 62 & 18,000 \\
\hline 7 & Channel excavation & $\mathrm{CY}$ & 4,000 & 20,000 \\
\hline \multicolumn{4}{|c|}{ Total Project Costs } & 375,280 \\
\hline
\end{tabular}

\subsection{Alternatives Considered}

Three alternatives were considered to improve the capability of drainage by increasing the amount water to be drained. The first is replacing the existing two-culvert drainage system with an open channel (restored to its natural condition as much as possible) and a road crossing structure that does not impair the flow of water. The second was to repair the existing two-culvert system. The third alternative is no action.

- Alternative 1, the proposed action, involves (1) removing two 96-inch diameter culverts, associated concrete wing walls, and concrete road structure; (2) excavating and cleaning the channel so that it is restored to its natural condition as much as possible, and (3) installation of a structure that permits vehicles to cross the channel but does not impair the flow of water through the channel. As part of the proposed project, debris and sludge that is currently affecting the water flow will be cleared and a 10-year or greater event will be mitigated. This alternative would be the best option.

- Alternative 2 is to repair the two-culvert drainage system. This includes removing the existing round reinforced concrete culverts and replacing them with square culverts. However, this option does not increase the drainage capacity of the channel and will continue to cause flooding

- Alternative 3 is no action. This alternative continues to place the community at risk of flooding. Therefore, this alternative is unacceptable.

\subsection{Quantification of the Project Benefits}

In the community, houses were flooded or nearly flooded in Jan. 2007, April 2007, June 2007, May 2007, and May 2008. However, the residents only have recorded damages for June 2007 in which many houses received one or more feet of water.

Flood frequency was determined from rainfall data for Jan. 2007, April 2007, June 2007, May 2008 and June 26th, $2007<$ Table 3>. Once the rainfall amount was identified through the National Climatic Data Center (NCDC), the frequency of the event was determined by comparing the rainfall data with the USGS Atlas of Depth Duration Frequency. Based on flooding or near flooding (Jan. 2007, Apr. 2007, May. 2007, June 2007, and May. 2008), the frequency of events is 2-year or less.

$<$ Table 3> Rainfall Amount on Flooding Events

\begin{tabular}{|c|c|c|c|}
\hline Year & Month & Date & $\begin{array}{c}\text { Rain for 24 } \\
\text { hours (inches) }\end{array}$ \\
\hline \hline 2007 & Jan. & 4 & 1.02 \\
\hline 2007 & Jan. & 14 & 1.94 \\
\hline 2007 & Jan. & 15 & 1.24 \\
\hline 2007 & Apr & 8 & 1.37 \\
\hline 2007 & May & 22 & 2.50 \\
\hline 2007 & May & 25 & 1.43 \\
\hline 2007 & May & 26 & 1.53 \\
\hline 2007 & June & 16 & 2.53 \\
\hline 2007 & June & 26 & 2.55 \\
\hline 2008 & May & 14 & 1.81 \\
\hline 2008 & May & 25 & 1.67 \\
\hline
\end{tabular}


Ensuring Economic Benefits of Mitigation Projects for Improving the Image of Construction Industry

The recorded damages from flooding on June 26th, 2007 are summarized in Table 4. Most of the residents impacted by flooding tracked and recorded their costs for repair. Official receipts and bills are sorted by residents and summed up for total flood damages.

$<$ Table 4> Summary of Flood Damage

\begin{tabular}{|r|l|c|c|r|}
\hline No & Name & $\begin{array}{c}\text { Built in } \\
\text { (Year) }\end{array}$ & $\begin{array}{c}\text { FFE } \\
\text { (Google Earth) }\end{array}$ & $\begin{array}{c}\text { Documented } \\
\text { Damages }\end{array}$ \\
\hline \hline 1 & Pe*** & 1995 & 557 & $\$ 10,107.7$ \\
\hline 2 & Mc*** & 1991 & 557 & $\$ 10,178.6$ \\
\hline 3 & Ca*** & 2000 & 557 & $\$ 448.0$ \\
\hline 4 & Br*** & 1995 & 555 & $\$ 6,122.3$ \\
\hline 5 & Ta*** & 1987 & 555 & $\$ 52,982.5$ \\
\hline 6 & De*** & 1986 & 555 & $\$ 10,392.8$ \\
\hline 7 & Du*** & 1986 & 555 & $\$ 7,203.9$ \\
\hline 8 & Ro*** & 1993 & 557 & $\$ 14,840.2$ \\
\hline 9 & $\mathrm{Ji} * * *$ & 1994 & 563 & $\$ 23,163.4$ \\
\hline 10 & Ru*** & 2004 & 559 & $\$ 7,071.9$ \\
\hline 11 & Eb*** & 2002 & 556 & $\$ 24,391.3$ \\
\hline 12 & Mi*** & vacant & 564 & $\$ 448.0$ \\
\hline \multicolumn{5}{|c|}{ Total Damages } \\
\hline
\end{tabular}

\subsection{Capability of the Proposed Project}

There was limited data available for the project area, so the hydraulic model was created using the best available data. The 10-foot contours, stream centerline, and road locations were downloaded from the Texas Natural Resources Information System (TNRIS) website. Aerial photos were obtained from the City of Austin GIS Data Sets websites. These were imported into ArcGIS and an input geometry file was created using HECGeo-RAS. A hydraulic model was created using the U.S. Corps of Engineers HEC-RAS modeling program. The flow data was taken from the 2008 FIS study for the Bell County.

This project modeled the flooding that resulted from the culvert bridge overtopping using the best data available. A water surface elevation of $555 \mathrm{ft}$ is considered overtopping of the structures that will begin to cause damage to the surrounding houses. The summary of water surface elevations is included in Table 5 .

$<$ Table 5> Summary of Water Surface Elevations

\begin{tabular}{|c|c|c|}
\hline \multirow{2}{*}{$\begin{array}{c}\text { Rainfall } \\
\text { Event }\end{array}$} & \multicolumn{2}{|c|}{ Water Surface Elevations (ft) } \\
\cline { 2 - 3 } & Culvert Bridge & $\begin{array}{c}\text { 40-ft Open-Span } \\
\text { Bridge }\end{array}$ \\
\hline \hline 10YR & 557.8 & 554.6 \\
\hline $25 Y R$ & 558.1 & 556.2 \\
\hline $50 Y R$ & 558.3 & 557.5 \\
\hline 100YR & 558.5 & 558.2 \\
\hline
\end{tabular}

The culvert bridge is overtopping for all storm events modeled: 10YR, 50YR, 100YR and 500YR. A 40-ft wide bridge opening was also modeled to replace the existing culvert. The bridge was able to withstand overtopping during the 10YR storm events.

\subsection{Calculation of Benefit Cost Ratio (BCR)}

The information obtained from the rainfall data, actual damages, and preliminary hydrology study were input into a BCA limited data (LD) module to calculate a benefit cost ratio [10]. The result of the BCA is summarized below in Fig. 2.

\begin{tabular}{|c|c|c|}
\hline Summary of Benefits and Costs & $\begin{array}{c}\text { Expected } \\
\text { Annual }\end{array}$ & $\begin{array}{l}\text { Present } \\
\text { Value }\end{array}$ \\
\hline Expected Annual Damages Before Mitigation & $\$ 83,675$ & $\$ 1,154,781$ \\
\hline Expected Annual Damages After Mitigation & $\$ 16,735$ & $\$ 230,957$ \\
\hline Expected Avoided Damages After Mitigation (BENEFITS) & $\$ 66,940$ & $\$ 923,825$ \\
\hline PROJECT COSTS & \multicolumn{2}{|c|}{$\$ 389,081$} \\
\hline PROJECT BENEFITS & \multicolumn{2}{|c|}{$\$ 923,825$} \\
\hline BENEFITS MINUS COSTS & \multicolumn{2}{|c|}{$\$ 534,744$} \\
\hline BENEFIT-COST RATIO & \multicolumn{2}{|c|}{2.37} \\
\hline
\end{tabular}

$<$ Fig. 2> Result of the Benefit Cost Analysis 


\section{Conclusions}

This paper examined the method for conducting benefit cost analysis with limited data to help state and local communities determine whether to proceed with natural hazard mitigation capital improvement project. Through a case study this paper showed the basic process of conducting a benefit cost analysis with limited data. In addition, it also suggested how to collect reliable evidences that prove damages resulting from the natural disasters. By using the proposed decision-making process, the Korean government and local communities can select an appropriate mitigation project.

As a result, the paper will assist many people who suffered from the flooding events and had difficulties in collecting evidences for flood damages to be easily supported by the government assistant programs. Consequently, it will help government and local communities get funding from the government, which in turns will improve the image of construction industry by preventing people from natural disasters.

\section{References}

[1] FEMA, "2009 Federal Disaster Declarations" Federal Emergency Management Agency, Washington, D.C., 2009

$<$ http://www.fema.gov/news/disasters.fema $>$.

[2] NCDC, "Billion Dollar U.S. Weather Disasters."

National Climatic Data Center, 2008

$<$ http://www.ncdc.noaa.gov/oa/reports/billionz.htm $1>$

[3] GAO, "Natural Hazard Mitigation: Various Mitigation Efforts but Federal Efforts Do Not Provide a Comprehensive Strategic Framework" GAO-07-403, United States Government Accountability Offices, Washington, D.C. 2007.

[4] FEMA, "Developing the Mitigation Plan: Identifying Mitigation Implementation Strategies"
FEMA 386-3, U.S. Department of Homeland Security, Federal Emergency Management Agency, Washington, D.C., 2003.

[5] FEMA, "Using the Hazard Mitigation Plan to Prepare Successful Mitigation Projects" FEMA 386-9, U.S. Department of Homeland Security, Federal Emergency Management Agency, Washington, D.C., 2008.

[6] C.L Menches, D. Kim, C-B, Son, and W-S Shin, "Improving the Image of Construction Industry in Selecting Mitigation Capital Projects" Proceeding of the 2014 International Industrial Information Systems, pp 144- 147, Chiang Mai, Thailand, Jan. 21 ${ }^{\text {th }}-$ Jan. $24^{\text {th }}, 2014$.

[7] D.R. Godschalk, T. Beatley, P. Berkey, D. J. Brower, E.J. Kaiser, C.C. Bohl, and R. M. Goebel, "Natural Hazard Mitigation-Recasting disaster policy and planning" Island Press, Washington, D.C., 1999

[8] FEMA, "Getting Started: Building Support for Mitigation Planning" FEMA 386-1, Department of Homeland Security, Federal Emergency Management Agency, Washington, D.C., 2002.

[9] State of Texas, "State of Texas Hazard Mitigation Plan" Texas Department of Public Safety, Austin, Texas, 2010.

[10] FEMA, "BCA Reference Guide" Department of Homeland Security, Federal Emergency Management Agency, Washington, D.C., 2009. 
Ensuring Economic Benefits of Mitigation Projects for Improving the Image of Construction Industry

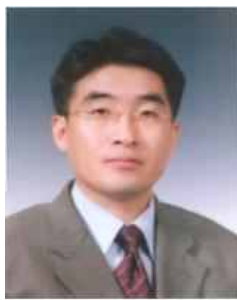

손 창 백 (Chang-Baek Son)

- 정회원, 주저자

- 1986년 8월: 중앙대학교 건축학학 과 (공학사)

- 1988년 8월: 중앙대학교, 건축공 학과-건설관리전공 (공학석사)

- 1993년 2월: 중앙대학교, 건축공학과-건설관리전공 (공학박사)

- 1993 7월-1998 2월: 대한주택공사 주택연구소 책임 연구원

- 1998 3월-현재: 세명대학교 건축공학과 정교수

- 관심분야: 건설관리 $(\mathrm{CM})$, 건설노무관리, 건설안전관 리, 건설생산성관리

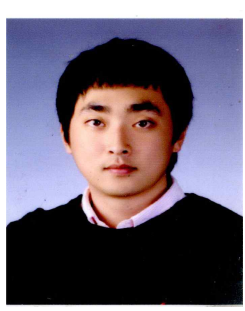

신 원 상 (Won-Sang Shin)

- 2011년 2월: 세명대학교 건축공학 과 (공학사)

- 2013년 2월: 세명대학교, 건설공 학과-건설관리전공 (공학석사)

- 2014년 3월: 세명 대학교, 건설공학과-건설관리전공, 박사과정

- 관심분야: 건설관리 $(\mathrm{CM})$, 건설노무관리, 건설안전관 리, BIM

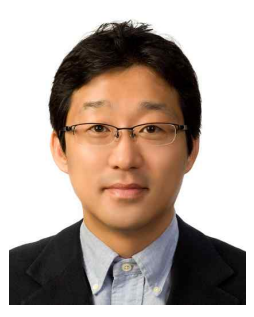

김 대 영 (Dae Young Kim)

- 정회원, 교신저자

- 2003년 2월: 부산대학교 건축공학 과 (공학사)

- 2006년 5월: The Univ. of Texas at Austin, 토목공학과-건설경영 전공 (공학석사)

- 2011년 12월: The Univ. of Texas at Austin, 토목 공학과-건설경영전공 (공학박사)

- 2012 1월-2013 2월: Center for Transportation Research at UT Austin (Postdoctoral Fellow)

- 2013 3월-현재: 동의대학교 건축공학과 조교수

- 관심분야: Project Success Strategy for Construction Management, Decision Support Modeling for Infrastructure Management, Hazard Mitigation Planning, and Statistical Analysis and Data Mining Applications.

논 문 접 수 일 : 2014년 03월 31일 1 차 수 정 완 료 일 : 2014년 05월 15일 2 차 수 정 완 료 일 : 2014년 05월 29일 게 재 확 정 일 : 2014년 06월 05일 